\title{
THE POLITICAL USE OF THE STAGE DURING THE REIGN OF JAMES I.
}

As early as 1874 the claim was made by Richard Simpson ${ }^{1)}$ that "in the days of Elizabeth and later the stage occupied not only a literary position, but a political one also", that "dramas were a part of the machinery of political propagandism." More recent investigations, while sometimes carrying to extremes certain ideas regarding the "topical element" in Elizabethan literature, have established the justification of this claim; the English dramatists - like their continental neighbors - were prone to meddle with affairs political and religious. Obviously the persistence of such a practice is to be largely accounted for, not only on the ground that men high in authority were encouraging the actors and playwrights who concerned themselves with affairs of Church and State, but also on the ground that the English sovereigns themselves were in spirit at least favorable to the use of the stage as a medium of religious and political expression.

When early in her reign the dramatists of England, perhaps at the instigation of the queen's counsellors, were endeavoring to influence Elizabeth's policy by instructing her through plays with a purpose, she usually listened graciously to their advice, even if she did not follow it, and on one occasion at least she is said to have ordered the presentation of dramas with marked political intent; ${ }^{2}$ ) when they became too impudent or seditious in their utterances against officials

1) Trans. Sh. Soc., 1874, p. 371.

2) Modern Philology, IX, p. 553. 
or the government, Elizabeth remonstrated and the offenders were punished - mildly, as a rule, however, owing to the queen's tolerant attitude or to the influence of the court politicians who stood behind the players and dramatists; and when diplomacy demanded that she disapprove of the treatment of foreign affairs in the theatre, she disapproved, but so slight were sometimes the results of this disapproval that one is led to conclude that on such occasions Elizabeth's heart was really not in her actions. Thus, to give only one illustration, when Bishop Quadra, early in her reign, complained that members of her Council were furnishing the arguments for plays directed against the King of Spain, the queen made promises and she issued proclamations; ${ }^{1}$ ) yet so half-hearted were her remonstrances or so determined the members of the Council that in 1562 this same bishop, when accused of having sent to the Spanish king certain leaves of John Bale's book satirizing Spain and her monarch, could reply as follows: ${ }^{2}$ ) "It is true I sent these leaves as I was tired of complaining to the Queen of the constant writing of books, farces and songs prejudicial to other princes, and seeing that notwithstanding her promises no attempt was made to put a stop to it."

Similar conditions manifest themselves in the reign of James I. The king favored satire directed at his enemies; he frequently silenced the impertinent allusions to himself, his family, or his favorites, but he rarely punished the offenders; and when diplomacy necessitated a royal frown at offensive plays, the monarch frowned and the offensive plays sometimes continued.

A good deal of evidence in support of the statements just made may be found in the discussions of Miss Gildersleeve and others; ${ }^{3}$ ) I offer additional evidence in the following

1) Ibid., pp. $545 \mathrm{ff}$.

2) Cal. State Papers, Spanish, 1558-67, p. 247.

3) A few of the references to controversial plays contained in the present paper have been noted by Miss Sullivan in her Court Masques of James $I$, which was published some time after my discussion was read before the Philological Association of the Pacific Coast. With the exception of a few slight changes made in consequence of the appearance of Miss Sullivan's work, the paper is printed in its original form. 
pages, the testimony during a considerable number of years of a large number of witnesses of somewhat diversified opinions and stations in life.

I shall first consider instances of satire on the stage that apparently met with the king's approval. The most notable examples of this are those plays which ridiculed his religious adversaries, the Puritans and the Catholics. Thompson 1) suggests that the king's hatred of Puritan principles, together with the depravity of his court, had something to do with the great abandon manifested soon after 1603 by the dramatists in their satire of the sect. Thompson, however, hardly gives the fact the significance it deserves. In all probability James himself delighted in the satire against his opponents; and it is not at all unlikely that many of the remarks derogatory to Puritans were introduced into the dramas primarily for the sovereign's delight, as was done with the references to the king's dislike of tobacco, his fondness for the chase, his desire of peace, and his eagerness for the union with Scotland. ${ }^{2}$ ) At any rate, it should be noted that two of the bitterest anti-Puritan plays, Middleton's Family of Love and The Puritan, were written during the years $1606-1607$, a period when James was having unusual difficulty with his religious adversaries; that the sect is ridiculed in the masques of the time; ${ }^{3}$ ) and that dramas containing much vicious satire against the Puritans - Marston's Dutch Courtesan, Jonson's Alchemist; Bartholomew Fair, and Staple of News - were acted at court as well as on the public stages. ${ }^{4}$ )

What James thought of bringing Puritans on the stage may be inferred from Carleton's description of a performance in 1620. Writing from the Hague in September of that year, he remarks: ${ }^{5}$ ) "In England all goeth prosperously and joyfully (thanks to God) as you will guess by the merry passing of the 5th of August at Salisbury, where there was

1) Puritans and the Stage, p. 207.

$\left.{ }^{2}\right)$ Reyher, Les Masques Anglais, pp. 277-97.

3) Cf. Jonson's Love Restored, and Chapman's Middle Temple Masque.

4) Fleay, Stage, pp. 175, 258.

$\left.{ }^{5}\right)$ Cal. State Papers, Venetian, 1619-21, p. 390, note. 
a show or play of twelve parts, wherein the Lord of Buckingham acted an Irish footman with all his habiliments and properties; the Marquis Hamilton a western pirate; the Earl of Montgomery a Welsh advocate of the bawdy court; the Earl of Northampton a cobbler and teacher of Birds to whistle; the Lord of Doncaster a neat barber; the young Lord Compton a tailor; the Lord Cromwell a merryman (also the fool); Sir Henry Rich a curious cook; Sir Edward Zouch a bearwood; Sir John Millicent a carier about of baboons; Sir George Goring a perfumer; and Sir William Fielding a Puritan that marred the play." 1)

"A Puritan that marred the play" is suggestive.

Again, there are good grounds for believing that James smiled his approval of those plays which satirized the Papists, a source of vexation and anxiety, especially during the early years of his reign. Miss Gildersleeve, ${ }^{2}$ ) speaking of dramas against Catholics about 1592, remarks: "So soon after the days of the Armada, it was natural to allow a disrespect to Spain and Catholicism which would have been promptly suppressed by the government in later years." And she cites the suppression of the Game of Chess in 1624. This particular play, however, was in all probability silenced, not because it was disrespectful to the Catholic religion, but because it was offensive to the Spanish government. But be this as it may, there is certainly nothing to show that during the years 1605 to 1610 at least, when, as a result of the Gunpowder Plot and the murder of Henry IV, the hatred against Rome was at its height, the king or his Council was

1) In connection with this passage should be read the words of Sir Anthony Weldon in his Court of King James: "After the King supped, he would come forth to see pastimes and fooleries; in which Sir Edward Zouch, Sir George Goring, and Sir John Finit were the cheife and Master Fools, (and surely the fooling got them more than any other's wisdom) sometimes presenting David Droman and Archer Armstrong, the King's foole, on the back of other fools, to tilt one another, till they fell together by the eares: sometimes they performed antick-dances. But Sir John Millicent, (who was never known before) was commended for notable fooling; and was indeed the best extemporary foole of them all" (Quoted in Nichols, Progresses of King James, II, p. 38, note).

2) Government Regulations, p. 92. 
seriously concerned with the suppression of dramatic performances derogatory to the Yatholic faith. The king himself made no secret of his animosity against the Pope and Catholics. In 1605, for example, in the presence of the Venetian and French ambassadors, he urged the students of Oxford to keep God's holy word and to fly and loathe "above all things the perfidious and cursed superstitions of Rome". ${ }^{1}$ ) On February 2 of the following year, Barnes' Devil's Charter, setting forth the perfidious career of Pope Alexander VI, was "played before his Majestie"; and on November 15, 1607, Giustinian, ${ }^{2}$ ) writing to the Doge and Senate concerning the effect produced in England by the attempted assassination of Father Paulo Sarpi, used the significant words: "They say that the wider this iniquitous affair is known the greater will grow the scandal. Nor will pulpit and theatre fail to refer to it, as is the custom in this country, to the damage of the Catholic Faith, as your Excellencies will understand better than I can explain." In the preceding February the Venetian Vincenzo Giustiniani ${ }^{3}$ ) had been greatly offended by the "violently and scurriously anti-Papist street shows" that were being presented in London. Obviously, then, the king early in his reign was by no means eager to prevent the deprecation of Roman Catholic matters upon the stage.

Nor is it probable that at any period during his reign James objected to plays solely because they were hostile to the Catholic faith. Thus, in 1618, Piero Contarini wrote back to Venice:4) "There is mortal hatred against the pope on the score of religion ... In their theatres and public comedies they constantly speak of the papacy with contempt and derision, and they never lose an opportunity of speaking slanderously about it."

Busino's comments) of the same year is well known, but it may be cited here: "The English deride our religion as

1) Cal. State Papers, Venetian, 1603-07, p. 270. Cf. also, for James' hatred of Pope, Nichols, Progresses of James, II, 245, etc., etc.

2) Cal. State Papers, Venetian, 1607-10, p. 60.

3) Cited by E.S. Bates in Nineteenth Century, Vol. 72, p. 118.

4) Cal. Slate Papers, Venetian, 1617-19, p. 421.

s) Ibid., p. 134. 
detestable and superstitious, and never represent any theatrical piece, not even a satirical tragi-comedy without larding it with the vices and iniquities of some Catholic churchman, which move them to laughter and much mockery to their own satisfaction and the regret of the good." Accounts of two plays follow, one being perhaps ${ }^{1)}$ The Duchess of Malfi, the other a "comedy" in which a very impious Franciscan friar, after playing a conspicuous part, is finally beheaded on the stage.

Even as late as 1623, it may be noted, the Flemish and Spanish ambassadors "were gratified with their reception at

1) The reviewer in the Nation for June 26, 1913, of Miss Sullivan's Court Masques of James $I$, where the words of Busino are quoted in fall (p. 177), is a little harsh, it seems to me, in his criticism of Miss Sullivan's treatment of the passage. The passage is, he says (p. 649), a well-known one describing Webster's Duchess of Malfi ; and the Venetian correspondent in affirming that the play is a "mockery" of the Catholic Church "has missed the point". The passage is well known, it is true, but is it absolutely certain that Busino had The Duchess of Malfi in mind? At any rate, the Cardinal in Webster's production does not poison his sister, the order of events is not the same in the drama and in the letter of Busino, and there seems to be no evidence that in The Duchess of Malfi, "an altar was raised on the stage, where he [Cardinal] pretended to perform service, ordering a procession".

But granting that Busino is describing Webster's play, then has he entirely "missed the point" in saying it was a "mockery" of the Catholic Church? It should at least be noted that certain elements of "muckery" could have been brought ont in the acting; that the Cardinal is certainly painted in the worst colors (cf. I, ii, $75 \mathrm{ff}$.); that one of the madmen is a secular priest $(1 \mathrm{~V}, \mathrm{ii})$; that the play contains several incidental raps at the Church, as for example $V$, iii, $17-20$; and finally that the wearing of certain robes on the stage and the service at the altar may well have been regarded as "mockery" by many besides the Venetian. Perhaps it is not out of order to note in this connection that in 1635 the Master of the Revels committed a broker to the Marshalsea "for lending a church-robe with the name of Jesus upon it to the players in Salisbury Court, to present a Flamen, a priest of the heathens" (Gildersleeve, p. 87); and that in 1639 the players at the Fortune were fined $£ 1000$ for setting on the stage an altar, basin, two candlesticks, and bowing down to them. The actors protested that the play was an old one revised, and that the altar was merely one to the heathen gods; nevertheless the Council decided that their condnct was in contempt of the ceremonies of the Church, and the players were fined accordingly (Cal. State Papers, Domestic, 1639, pp.140-41). 
Cambridge, but declined the play, on being told that the argument was chiefly about a .Jesuit and a Puritan". 1)

If James was favorable to -satire directed against his enemies, he was bitterly opposed to those dramas which concerned themselves too impudently with his own person, his family, or his favorites. On ascending the English throne, one of the first things he did was to decree, in 1604, that the crown alone was to have the power to license theatrical companies. This assumption of a power formerly enjoyed by noblemen is not to be explained solely on the ground that the king wished to grant to a few favored companies a practical monopoly of playing in London. James was naturally suspicious regarding the treatment of his own affairs in literary productions. ${ }^{2}$ ) Hence, recognizing that in the reign of his predecessor various politicians of note had been instrumental in introducing upon the stage matter deprecatory of their rivals, ${ }^{3}$ ) the sovereign perhaps had for his chief motive the safeguarding of himself and friends. If such was his purpose, he was by no means successful; for accompanying the period of his great unpopularity in consequence of his partiality to the Scots and his refusal to declare war against Spain, dramatists as well as pamphleteers and preachers took it upon themselves to castigate their monarch; and during the years 1605-1608 allusions are numerous to the disrespectful treatment of the English king in the theatres. The remarks on the subject by Calvert in 1605 and the French ambassador

1) Cal. State Papers, Domestic, 1619-23, p. 517. Thompson quoted this passage in his Puritans and Stage, p. 247, but erred in saying that the French, instead of Flemish, ambassador refused to attend the play.

2) Note, for example, his objections to the play against the Scots in 1598 (Cal. State Papers, Scottish, 1509-1603, p. 749); his distrust of the conclusion of Barnaby Rich's Farewell in 1595 (ibid., p. 683); his suspicion of varions other productions between 1590 and 1610 (Cal. State Papers, Domestic, 1603-10, passim; ibid., Venetian, 1603-07, 1607-10, passim).

3) To cite only one passage that indicates the frequency of this sort of thing, a quotation from Essex's letter to the queen, May 12, 1600, is interesting: "The prating tavern haunter speaks of me what he lists; the frantic libeller writes of me what he lists; they print me and make me speak to the world, and shortly they will play me upon the stage." (Cal. State Papers, Domestic, 1598-1601, p. 435.) 
in $1608^{1)}$ are well known. About 1606 the author of a tract on hunting ${ }^{2}$ ) comments on the madness of the comedians in censuring their sovereign "under feigned persons". "Surely", he continues, "though their poets for these many years have for the most part left fools and devils out of their plays, yet now on the sudden they make them all play the fools most notoriously and impudently in meddling with him (in way of taxation) by whom they live, and have in manner their very living." Noblemen and government officials likewise were satirized by the dramatists. The induction to Day's Isle of Gulls (1606), a play, as we shall see later, which perhaps caused considerable agitation as a result of its political satire, makes evident the fact that spectators of the time were calling for dramas in which the lives of great men were "charactered". According to Haslewood, 3 ) the author of an unpublished tract written about 1606, censures the players "for the indirect attacks made by them upon the Nobility, under borrowed names of foreign Dukes and feigned persons"; and in his sermon of 1607 , Crashaw, ${ }^{4}$ ) after remarking on the introduction of "holy things upon the stage", exclaims, "No marvel though the worthiest and mightiest men escape not, when God himselfe is so abused". Common Sense in Lingua (pub. 1607), when informed that he is to be ridiculed on the stage, exclaims (II, iv): " 0 times! 0 manners! when boys dare to traduce men in authority; was ever such an attempt heard?" And when he remarks in answer to Memory's assertion that Aristophanes ridiculed Socrates on the stage, "In those days it was lawful, but now the abise of such liberty is insufferable", Phantastes significantly comments, "Think what you will. I think 'tis done". Much later, Heywood in his Apology for Actors (1612) lamented the boldness of his brethren as follows: "Now, to speake of some abuse lately crept into the quality, as an inveighing against the state, the court, the law, the citty, and their governements,

1) cf. Gildersleeve, pp. 101, 107-08.

2) Quoted by Simpson, Trans. Sh. Soc., 1874, p. 375.

8) Furnivall's ed. of Stubbes' Anatomy of Abuses, Forewords to Part 1, p. 79. Same as the tract on hunting above?

4) Quoted by Thompson, Puritans and Stage, p. 131. 
with the particularizing of private men's humors (yet alive), noblemen and others: I know it distastes many; neither do I in any way approve it, nor dare I by any meanes excuse it." 1) And numerous passages similar to those above are extant.

Under such circumstances it is not surprising that James should have issued, perhaps rather early in his reign, that "commandment and restraint given against the representing of any modern Christian kings in those stage-plays" referred to in August, 1624. Nor is it surprising to find the government interfering more than once with the presentation of offensive plays. Miss Gildersleeve ${ }^{2}$ ) has ably discussed in this connection "the tragedy of Gowry" (1604), and Eastward Ho (1605).

Her discussion of Day's Isle of Gulls must be revised in view of the letter written to Sir Thomas Edmondes by Sir Edward Hoby on March 7, 1606. Discussing events that apparently transpired between the 15th and 17th of the preceding month, he says: ${ }^{3}$ ) "At this time was much speech of a play in the Black Friars, where, in the 'Isle of the Gulls', from the highest to the lowest, all men's parts were acted of two divers nations: as I understand sundry were committed to Bridewell."

Now the passage above, when read in connection with the words that precede and follow it, implies that Sir Edward was referring to "much speech" in Parliament regarding this objectionable play, or "much speech" by the members of Parliament; and that he did mean as much is made probable by the fact that at the very time of which he is speaking, February 17th, a bill to "restrain many abuses of players" was actually read in the House of Commons. ${ }^{4}$ ) This was the first reading of the well-known bill for the preventing of the great abuse of the holy name of God in stage plays, ${ }^{5}$ ) ete., which was sent up to the House of Lords on April 17, and passed by that body on May 19th. ${ }^{6}$ )

1) Sh. Soc. Pub., III, p. 61.

2) Gov. Regulations, pp. $100 \mathrm{ff}$.

2) Birch, Court and Times of James, I, pp. 60-61.

4) Journals of the House of Commons, I, p. 270.

5) Statutes of the Realm, IV, Pt. ii, p. 1097.

6) Journals of the House of Lords, II, pp. 416, 436. Anglia. N. r. XXVI. 
From what precedes, then, it seems that Day's Isle of Gulls, while not blasphemous or irreverent as it has come down to us, ${ }^{1}$ ) was one of the motives which led a Parliament puritanically inclined to legislate at this particular period against certain abuses of the players. And there are other indications that during the stirring period of 1606 to 1610 the government was rather active in guarding against undesirable performances. Perhaps Day, for example; was speaking from personal experience when he had the Prologue affirm in the printed version (1606) of this same Isle of Gulls,

"If poetick rage

Strikes at abuse or ope the vaine of sinne,

$\mathrm{He}$ [the poet] is straight inform'd against for libelling" -

a sentiment echoed in the same writer's Parliament of Bees, possibly ${ }^{2}$ ) written as early as 1607 :

Doe call 'em [satires] Libels."

"Tart Authority

It is interesting, too, to note that in the same production (p. 36) Iltriste desires Poetaster to write a satire against the "Mr. Bee"; and Poetaster promptly replies:

"That thunder doth deter

And fright my Muse: I will not wade in ills

Beyond my depth, nor dare I pluck the quils,

Of which I make pens, out of the eagles claw.

Know I am a loyall subject."

At the conclusion of his speech he is upbraided by Iltriste for being a servile instead of a true poet, who

"holds his reputation so deare

As neither flattering hope nor servile feare

Can bribe his pen to temporize with kings."

1) Birch (Court and Times of James, I, p. 61) and E. K. Chambers (Mod. Lang. Review, IV, p. 158) both identify as Day's production the drama described by Hoby; and there seems to be no reason for objecting to this identification. The acted and printed versions of the play, however, probably differed considerably. For Fleay's discussion of the allegory of The Isle of Gulls, see his Biographical Chronicle, I, pp. 109-10.

2) For the evidence, by no means conclusive, that this production was published in 1607, see Bullen's edition of Day, Introduction, p. 25. 
More to the point is the statement in the Epistle to $\mathrm{H}$. Parrot's More the Merrier (1608): ${ }^{1}$ )

"As for satyrick inveighing at any man's private person (a kind of writing which, of late, seemes to have been very familiar among our poets and players, to their cost), my reader is to seeke it elsewhere."

And finally, an interesting case of government regulation is revealed in a letter of February 10, 1610, written by Contarini and Correr: ${ }^{2}$ ) "Lady Arabella [Stuart] is seldom seen outside her rooms and lives in greater dejection than ever. She complains that in a certain comedy the playwright introduced an allusion to her person and the part played by the Prince of Moldavia. The play was suppressed." I have shown elsewhere that this is a reference to Jonson's Epicoene.

Examples, too, of what we of the twentieth century would be inclined to regard as excessive suspicion on the part of the king and government may be cited. Buc's expurgated version of the Second Mayden's Tragedy in 1611 is a case in point. ${ }^{3}$ ) More interesting is the comment of Girolamo Lando, ${ }^{4}$ ) January 10, 1620: "In connection with the subject of comedians, I ought not to conceal the following event from your Serenity, owing to the mystery that it involves. The comedians of the prince, in the presence of the king his father, played a drama the other day in which a king with his two sons has one of them put to death, simply upon suspicion that he wished to deprive him of his crown, and the other son actually did deprive him of it afterwards. This moved the king in an extraordinary manner, both inwardly and outwardly. In this country however the comedians have absolute liberty to say whatever they wish against any one soever, so the only demonstration against them will be the words spoken by the king." 5)

1) Quoted in Pub. Shakespeare Soc., III, p. 66. Can this passage be connected with Marston's committal to Newgate in June, 1608? Cf. Mod. Lang. Review, IX, 99.

2) Cal. State Papers, Venetian, 1607-10, p. 427.

3) Cf. Gildersleeve, pp. 109-11.

4) Cal. State Papers, Venetian, 1619-21, p. 111.

5) This comment is also of value in showing that plays were acted at court during the Christmas of $1619-20$. Hence it invalidates the inference of J. T. Murray (Eng. Dram. Companies, II, p. 7, note 3) that owing to the death of Queen Anne in March, 1619, no plays were presented at court during this season. That plays were being presented at court as 
James no doubt recalled the rumors that he instigated the death of Prince Henry in 1612; and in view of James' temper and the fact that Prince Charles' players were guilty of this very "suggestive" play, we may infer that in spite of the liberty given actors "the words spoken by the king" were no mild ones.

Another interesting illustration of excessive precaution is perhaps Robert Taylor's The Hog Hath Lost His Pearl. As we learn from a letter written on February 23, 1613,1) by Sir Henry Wotton, "on Sunday last at night" the sheriffs of London broke up the performance of this particular play as it was being presented at the Whitefriars by a number of apprentices, who "invited thither (as it would seem) rather their mistresses than their masters". Says Wotton: "Towards the end of the Play, the Sheriffs (who by chance had heard of it) came in (as they say) and carried some six or seven of them to perform the last Act at Bridewell; the rest are fled. Now it is strange to hear how sharp-witted the City is, for they will needs have Sir John Swinerton the Lord Maior be meant by the Hog, and the late Lord Treasurer by the Pearl."

The similarity between the "Hog" of the title and the Mayor's name, the facts that Swinerton had in the preceding October lost the favor of the Lord Treasurer ${ }^{2}$ ) and that he

early as November, 1619, we know from a letter written by Marioni on November 15, wherein it is stated that the king, although busy with study and business, "does not fail to witness almost every evening the comedies which are now being presented at the Court". (Cal. State Papers, Venetian, 1619-21, p. 47.) On March 4, 1620, says Camden, the Prince invited the "Peers to a Banquet in Somerset-House, and to a Play" (Kennett, Complete Hist. of Eng., II, 653).

Furthermore, in connection with the passages above, the record under January 10, 1620, of the king's men at Coventry should be considered. This is probably a reference to Errington's provincial company, as Murray is inclined to believe, but refuses to do so, since he finds no record of the king's company acting at court during the Christmas of 1619-20. In view of what precedes, it seems probable that the company was acting at court late in 1619 and early in 1620 . Again, since the Coventry record of 1620 seems to refer to Errington's company, the date, cir. 1622, given by Murray as the date of its formation, is perhaps incorrect.

1) Cf. Smith's edition of Wotton, II, p. 13.

*) Cal. State Papers, Domestrc, 1610-13, p. 150. 
was apparently unpopular with the merchants at the time,1) and the coincidence that, when the play was interrupted, the Lord Mayor was actually patroling the city as a result of anticipated riots, ${ }^{2}$ ) the eagerness of the age to find personalities in literary productions - these things quite naturally account for the surmise of the London citizens. But Wotton's last remark is evidently the sarcastic comment of one in possession of the facts in the case regarding the suppression of the play.

What were the facts in the case? Fleay asserts that the production was interrupted because it was acted on Sunday; ${ }^{3}$ ) Miss Gildersleeve conjectures that it was stopped because it had not been authorized by the Master of the Revels. 4) Neither explanation is satisfactory. Perhaps more convincing would be the conjecture that the sheriffs objected to a night performance by apprentices who had for an audience "rather their mistresses than their masters"; and yet it seems to me that a more satisfactory explanation is possible. I herewith offer my solution.

The play, as it has reached us, is, to all appearances, entirely harmless in its content; and it is difficult so see how even the seventeenth century could have detected in the story analogies to contemporary events. Why, then, its suppression? I suggest that it was unfortunate in its title and its untimely appearance.

Now it will be noted that the play was acted on Sunday, February 21st, at the conclusion of the elaborate entertainments celebrating the marriage, on February 14th, of Princess Elizabeth to the Elector Palatine; and at the very hour when the play was interrupted the king and those who had

1) Ibid., p. 147 .

$\left.{ }^{2}\right)$ Cf. below. Says Sir Richard Baker (Hist. of Kings of Eng., ed. 1653 , p. 601) describing the marriage of Princess Elizabeth, "the Lord Maior and Aldermen gave the Bride a Chain of Orientall Pearle, valued at two thousand pounds". This gift was presented on Feb. 14th in behalf of the city (Nichols, Progresses of King James, II, 553). Is it possible that this circumstance had anything to do with arousing suspicion one week later regarding a play titled The Hog Hath Lost His Pearl?

8) Hist. of Stage, p. 251.

4) Gov. Regulations, pp. 112-13. 
participated in the entertainments at court were enjoying "a great Supper" paid for by those whom James and his party had defeated in running at the ring. ${ }^{1)}$ And it will also be noted that the performance was stopped at a time of unusual stringency as a result of the uneasiness on the part of the king and authorities. ${ }^{2}$ ) On February 8th, Foscarini ${ }^{3}$ ) stated that James had heard of a plot to kill him, and that as a result of this anxiety "extra guards were patroling the city, and the Lord Mayor had begun to make the round at night." On March 1st he wrote that during the festivities in honor of Elizabeth's marriage "the gates of the city were strictly guarded to prevent any danger" $;^{4}$ ) while on February 11 th, Carleton had written that as a result of suspected treachery the city had raised five hundred musketeers to guard the court. ${ }^{5}$ ) And finally, John King, Bishop of London, wrote to Carleton on February 27th, that the "festivities have passed, not without caution against 'some practice so much prognosticated". Thus, he continues, the king "shows his people that he will not be surprised sleeping". ${ }^{6}$ )

In a time of such uneasiness, then, and in such an epoch when more than once conspirators and rioters had assembled at the theatre prior to their outbreaks, ${ }^{7}$ ) it is natural that James and the city authorities should look with the profoundest suspicion upon the presentation of even an entirely harmless play, especially when the title of that play The Hog Hath Lost His Pearl - was so capable of suggesting to the authorities James (the hog) and his very

1) Nichols, Progresses of King James, II, p. 601.

2) Note the great precaution against unruly conduct brought out in Carleton's letter of Feb. 4th, to Chamberlain: "We have here in this time all this carnival so few mischiefs and disorders, that it is apparent those scandalous accidents which were wont to happen, to the disgrace of this government, were not so impossible to be remedied as were always held" (Birch, Court and Times of James I., II, p. 221).

3) Cal. State Papers, Venetian, 1610-13, p. 491.

4) Cal. State Papers, Venetian, 1610-13, p. 500. II, 524.

5) Ibid., Domestic, 1610-13, p. 169; Nichols, Progresses of James,

6) Cal. State Papers, Domestic, 1610-13, p.173. Cf. also Lord Somers' Tracts, ed. Scott, II, 279.

ग) Cf. Holinshed, III, pp. 963-64; Gildersleeve, pp. 179 ff., etc. 
popular daughter, Elizabeth (the pearl), who was in a sense really lost to him through her marriage to the Elector. Government interference in this particular case, then, was perhaps due to extreme precaution rather than to actual objection to the nature of the play.

So much for those plays which, dealing with domestic matters, were especially objectionable to the king for personal or political reasons, and the king's attempts to suppress them. There remains for brief discussion instances of the sovereign's objection, for diplomatic reasons, to plays dealing with foreign affairs.

Most interesting in this connection are the dramas which late in James' reign were directed against Spain. Spanish ambassadors had, as a rule, never been popular in England. Gondomar, the special agent sent to conduct negotiations for a marriage between Prince Charles and the Spanish Infanta, was especially distasteful, as a result of his mission; hence soon after his arrival in London the pamphleteers, playwrights, and actors began their war against him. ${ }^{1)}$ In 1617, Middleton's pageant, The Triumphs of Honour and Industry, written for the mayoralty of George Howles, was presented. The words of the Spaniard preserved in the production are certainly not derogatory to Spain and the Spanish. But let us turn to Busino's account of the acting. "Among the figures represented", says Busino, "was a Spaniard, wonderfully true to life, who imitated the gestures of that nation perfectly. He wore small black moustachios and a hat and cape in the Spanish fashion with a ruff round his neck and others about his wrists, nine inches deep. He kept kissing his hands, right and left, but especially to the Spanish Ambassador, who was a short distance from us, in such wise as to elicit roars of laughter from the multitude". ${ }^{2}$ )

Was the actor giving the spectators a picture of Gondomar in action ? ${ }^{3}$ ) That he had striking mannerisms may

1) For several of the tracts written against Spain and the Spanish Match, see Lord Somers' Tracts, ed. Scott, II, $469 \mathrm{ff}$.

2) Cal. State Papers, Venetian, 1617-19, p. 62.

3) This incident probably is an illustration of one reason why it is difficult for us to detect the objectionable features in certain plays; that 
be inferred from Chamberlain's comment that the actors in The Game at Chess impersonated the Spaniard "with all his graces and faces."

More serious things happened later; for when Gondomar's mission in England became generally known, a howl of protest arose on every side. Vox Populi, says Lando ${ }^{1}$ ) in 1620, made Gondomar "foam with wrath in every direction"; numerous pamphlets against the Spanish ambassador and his king appeared late in the same year and early in $1621 ;^{2}$ ) in April, 1621, the apprentices attacked Gondomar on his way about the streets of London, and soon afterwards a royal proclamation forbade the citizen to meddle in Spanish affairs, a proclamation, observes Lando, ${ }^{3}$ ) which "rather loosens men's tongues than restrains them". Gondomar himself seems to have realized the desirability of winning the favor of the players; for on July 21, 1621, as a result of growing "affable and familiar", remarks Chamberlain sarcastically, he went with his "whole traine" to a common play at the Fortune; "and the Players (not to be overcome with courtesy) made him a Banquet, when the Play was done, in the garden adjoining". ${ }^{4}$ ) But in spite of proclamations and diplomacy the satire of Gondomar continued in the theatre; and on August 15, 1623, we have John Howell ${ }^{5}$ ) writing from abroad against the "Ballads and Pasquils and Fopperies and Plays" made "against Gondomar for doing the King his master's business".

The expression in the London theatres of the hostility against Spain and Gondomar of course reached its climax in Middleton's Game at Chess, acted for nine days in August, 1624, a production which, although "of no great merit from what they say", to use the words of the Venetian ambassador, nevertheless on account of "curiosity at the subject" gained for the players "300 gold crowns" at each performance,

is; the fact that the objectionable feature, since it was sometimes merely the acting, does not survive in the text.

1) Cal. State Papers, Venetian, 1619-21, p. 491.

2) Ibid., p. 553, and above.

3) Ibid., 1621-23, p. 108.

4) Murray, Eng. Dram. Cos., I, p. 213.

s) Cited by Ward, Hist. Eng. Dram. Lit., II, p. 528 note. 
according to one account, 1) "100£ a night", according to another. ${ }^{2}$ ) Why such obvious treatment of political events should have been tolerated at such a time may occasion some slight surprise. Indeed, it caused the king himself surprise, who, according to Secretary Conway, ${ }^{3}$ ) wondered both at the boldness of the actors and the neglect of authorities who allowed the performance of such a piece. Just why the Master of the Revels licensed the play is not clear, but why it was allowed to continue on the stage for nine days is explained by the sway of Buckingham and the popular sentiment against Spain at the time, and by the fact that the players themselves apparently attempted to secure an extended and uninterrupted run of the play by presenting it under different titles. ${ }^{4}$ )

Nor is it at all probable that James himself was nearly so vigilant or so severe when diplomatic rather than personal reasons urged his interference with dramatic activities. At any rate, his leniency in the case of The Game at Chess is somewhat surprising. And it is entirely possible that even here the personal element had considerable to do with the first burst of anger on the king's part when he learned of the negligence of his officials. At least Secretary Conway's letter of August 12th to the Privy Council implies that his Majesty was vexed as much at his own representation upon the stage "in a rude and dishonorable fashion" as he was at the insult to Gondomar and the Spanish king; ${ }^{5}$ ) and

1) Salvietti, Cal. State Papers, Venetian, 1623-25, p. 425 note.

2) Sir Francise Nethersole, ibid., Domestic, 1623-25, p. 327.

3) Gildersleeve, pp. 119-20.

+) Cal. State Papers, Venetian, 1623-25, p. 425. Valaresso's account of the play, written on Aug. 20th, is interesting enough to be quoted: "In one of the public mercenary theatres here they have recently given several representations under different names of many of the circumstances about the marriage with the Infanta. The work is of no great merit from what they say, but it drew great crowds from curiosity at the subject. The Spaniards are touched from their tricks being discovered, but the king's reputation is affected much more deeply by representing the case with which he was deceived. The Spanish ambassador has made a remonstrance, and it is thought they will at least punish the author." Cf. also his comment of Sept. 6 (ibid., p. 432).

s) Bullen's edition of Middleton, I, pp. Ixxxiii-iv. 
Valaresso, 1) writing on August 20th, explains the objections to the play as follows: "The Spaniards are touched from their tricks being discovered, but the king's reputation is affected much more deeply by representing the case with which he was deceived." Having referred the case to the Privy Council - "to give them some employment and rid himself of the odium of such decisions", says Valaresso ${ }^{2}$ ) James soon cooled of his anger. On August 27th he greatly modified ${ }^{3}$ ) the somewhat stern justice administered to "his poore servants" by his Council. In a few weeks the "poore servants" were in trouble again as the result of acting without license The Spanish Viceroy, a drama that was perhaps concerned with contemporary Spanish affairs. ${ }^{4}$ )

In the provinces, too, the players at this very exciting time were apparently introducing Spanish matters into their plays. So active were they that on November 20, 1622, the Lord Chamberlain considered it necessary to write to all the mayors and sheriffs of the realm warning them against those actors who, unprovided with a licence signed by Sir John Ashby, nevertheless do present in many places dramas and shows "wch for ye most pt are full of scandall \& offence both against the Church \& State". ${ }^{\text {s) }}$

That some of these plays so referred to dealt with matters of Spain and that on one occasion at least the provincial authorities put into execution the orders from Whitehall, is revealed by an incident which took place at Norwich in April, 1624, and which concerns a production that was probably a source for Middleton's notorious Game at Chess. ${ }^{6}$ ) One Francis Wambur, it seems, had presented to the city authorities his licence to act, and on being refused permission to play in consequence of certain orders issued by the Privy Council, nevertheless fastened on the gate of his landlord's

1) Cal. State Papers, Venetian, 1623-25, p. 425.

2) Ibid., p. 432.

3) Bullen, pp. Ixxxii-iv; Gildersleeve, p. 116.

4) On this very uncertain play, see Gildersleeve, pp. 77, 122; Ward, Eng. Dram. Lit., II, p. 530, note; III, pp. 8-9.

5) Murray, II, pp. 351-52.

6) For a discussion of the sources of this play, see Bullen's edition of Middleton, VII, p. 4. 
house the following notice: "Here within this place at one of the clocke shalbe acted an excelent new Comedy called the Spanishe Contract by the Princesse servants, vivat Rex." l) Wambur was arrested.

So agitated indeed was England about the Spanish question that the pruning knife had to be used even on the masques composed to be acted before James himself. The comment of a Venetian, Valaresso, ${ }^{2}$ ) written on January 19, 1624, is interesting: "As regards his [James'] instability or rather his stability in evil, I need only mention that the usual verses written for the masque containing some rather free remarks against the Spaniards, they were altered by his command, and while in others this might be the result of prudence, in him it is nothing but the fear of offending the Spaniards."

This is a reference to Jonson's Neptune's Triumph which was postponed, and finally abandoned, probably for political reasons. ${ }^{3}$ ) A considerable portion of the production, however, was incorporated into the masque acted early in the next year, The Fortunate Isles and Their Union. Zuane Pesaro describes the performance as follows: ${ }^{4}$ ) "Last Sunday the prince gave a splendid masque, with much machinery and most beautiful scenery ..... The residents of Spain and Flanders were present, and it is believed that many jests against the Spaniards were omitted on their account."

With this bit of diplomacy my brief resumé of the political use of the stage under James I comes to a close. Some of the references given above have already been utilized by students of the drama; the majority of them have not. These by no means represent all the allusions to religious and political plays that might be accumulated from the state papers of the early seventeenth century. They are given here with the hope that some one better prepared for the task than I may examine the letters and

1) Murray, II, p. 348 .

2) Cal. State Papers, Venetian, 1623-25, p. 196.

8) See Brotanek, Eng. Maskenspiele, p. 359; Reyher, p. 305.

4) Letter of Jan. 24, 1625. Cal. State Papers, Venetian, 1623-25, p. 564 . 
reports sent home by the representatives of the French. the Florentine, and the Spanish governments. A careful examination of such documents will, I am convinced, reveal much that is yet unknown regarding an extremely important function of our early stage, and further corroborate the assertion made long ago that in the time of Elizabeth and later "dramas were a part of the machinery of political propagandism".

Trinity College, Durham, N. C., U. S. A.

T. S. Graves. 